\title{
Effects of Employee Satisfaction on Attrition of Military Officers at Hungarian Defence Forces (HDF) Military Hospital
}

\author{
Szilárd JASZTRAB ${ }^{1}$
}

\begin{abstract}
In the results of this study, I examined the employee satisfaction survey given between 2011 and 2014, and I compared it with the research on emigration conducted at the Hungarian Medical Chamber and at the Hungarian Resident Association. We received between 412 and 801 answers annually. The importance of the topic is indicated by the fact that the media regularly deals with this issue and the shortage of doctors in the military severely compromises fighting ability. The Organisation for Economic Co-operation and Development (OECD) predicts that by 2022 the European Union will have a shortage of 1 million physicians, which affects $14 \%$ of the total health activities. The situation is further worsened by the fact that the Hungarian civil sector (including pharmaceutical companies) presents a serious draining effect as well.
\end{abstract}

Keywords: employee's satisfaction, attrition, disarmament of military doctors, Ministry of Defence, Military Hospital

\section{Research}

Non-representative survey-results_obtained in high schools_give a partial explanation why military service as a career option is not popular among young people before making career choices. Romantic notions are attributed to Hungarian soldiers in the military service. On the other hand, they are viewed negatively based on stereotypes made by the parents' and grandparents' generation. The view of society concerning soldiery, did not change after the regime change. The image of military life was not widely re-evaluated after the elimination of line infantry, draft and the professionalization of the profession. [5]

For what reasons does somebody opt for the military? There are several possibilities such as the idea of protecting the homeland, the possibilities of high-level professional learning, new challenges and career or a lack of other options. Nowadays, according to social public opinion the emotional part of the military has been pushed into the background. [6]

Professionals conducted career tests with students, who wanted to be doctors or soldiers. The study detected a relatively early determination. In the sample, $24 \%$ decided to become soldiers, and had made their decision. $41 \%$ of the students who started their studies decided in high school to become a doctor or soldier. The presumption of existential security can promote positive attitude enforcement towards military careers. Recent test results confirm the conclusion of the research: in the psychological and personal aspects of a military career existential security as a decisive factor is crucial. As for the social context, the family background is the decisive factor. The aspect of a commissioner livelihood is a very important

1 Captain, Budapest, HDF Military Hospital; e-mail: jasztrabszilard@gmail.com 
motivating factor when choosing career and even later on. The "secure job" as a motivation, in many cases comes from the living condition of a person. [7]

In recent times, the prestige of the armed organizations and professions has gradually decreased. The decrease of prestige is supported by labour market analyses. These labour market analyses were carried out to establish the occupation policy of the army. The international trend is that most members of the military stem from a poorer class of society. Primarily, they come from physical worker families. [8]

For those, who choose a military career, the livelihood, as motivation plays a prominent role. However, many medical students need to re-evaluate their former idea about their career when they face the anomalous state of the national health care during their residency period. The state of national health care can often lead to migration or changing of jobs among young doctors. Many young people decide on other jobs or migration, because of different reasons: aversion towards discipline in the military, regional disparities in the medical community, contradictions in parasolvency (a kind of mandatory gratuity unique to the sector), competition for patients at a doctor's office and among private patients. In this situation, the military has a solution for the medical students. The Hungarian Defence Forces (HDF) have a scholarship program created to stop students migrating abroad. The scholarship supports students who have qualifications which cannot be obtained in military institutions. The positions are filled with the help of the scholarship program. The scholarship program is based on statute 9/2013. (VIII.12.) HM and the 2012. CCV regulations. The scholarship scheme allows contractual employment for doctors and medical students. The program prescribes the execution of basic training and the adoption of the first offered rota. Contractual legal relationship is necessary for successful applicants. The successful applicants start to work as career starters for the HDF. They work as doctors and practice their profession. The eligibility conditions are the same for professionals and contract soldiers alike. [9]

Working abroad and migration are often interrelated phenomena. Many people who work abroad often decide to permanently emigrate. Migration takes place within the country and outside the country. According to literature data, emigration can have many reasons which coincide with various viewpoints: macro-micro, push-pull and cyclic-structural effects. The reasons need to be better examined, because it can be concluded that the workers return to the domestic labour supply when the cycle goes up. During periods of crisis, the unemployment rate increases, which as a pushing effect increases the rate of migration, while the high rate of job finding is the puller effect. The cyclical reasons include the unemployment rate, differences in employment opportunities between the sending and receiving countries. For people who opt for migration, the employment opportunities are significant. Structural reasons include wage differentials, which are key factors in the decision to work abroad. The wage difference must be significant, since the person is able to cover the costs of relocation and integration. In addition, the international movement of labour allows the equalization of wages between nations. Similar languages being spoken in the sending and receiving countries can also increase the probability of migration. Studies show that this process works only to a certain degree, because it reaches a saturation level. The decrease of administrative obstructions is another positive factor leading to working abroad. There are differences between the sending and receiving countries in the social and education systems. The cultural environment of the country - the general political mood, exclusion, instability-are all able to enhance migration. [10] 
The domestic labour market, affected by regional—sectoral inequalities-also experiences labour shortages and oversupply, as well as the departure of highly skilled workers, generating skill shortages (health care workers, IT specialists and engineers). As such, it must cope with more dissonances. The migration has positive and negative effects on the sending country. The study of the National Bank of Hungary (MNB) examined the effects of the migration on the sending country from $4+1$ aspects. Among them is the decreasing of the population. With a smaller population, there is a smaller number of unemployment as well. Negative effects include demographic trends and migration of young people. The sustainability of the pension and health care system are increasingly in danger. From the perspective of selective migration, if the less productive individuals go to work abroad, the domestic average productivity increases. Otherwise, if the more productive individuals go to work abroad, the average productivity decreases at home. There are more reasons in the background. If the emigration is increasing or is at a high level, the domestic labour market can offer more work opportunities and less effort is needed to hold a job or to obtain it. From the workers' perspective, a decrease in their motivation is in direct proportion with their productivity. [12]

After the regime change, detailed timelines are available about employment trends, including data about emigration. For example, the number of foreign workers increased significantly: from 2009 to 2013, at determined moments of time: October to December. Within all workers, the proportions of Hungarian foreign workers more than doubled. [13]

Some surveys show a clear picture of the age groups. Among the foreign workers, the young adults represent the largest group-predominantly the 18-35 years age group and the 18-50 years age group. [14] On the basis of educational attainment, a higher proportion of graduates choose to work abroad. Among the graduates, four times more choose to work abroad, than people with low educational attainment. In 2004, the proportion of money sent home by the foreign workers, jumped over $1.5 \%$. Of course, this change happened within the domestic GDP. These changes draw politics attention to migration and working abroad. [14]

In case somebody with a profession that is in oversupply in our country goes abroad, the domestic situation may improve. The mismatch problems may show a negative trend, if somebody goes abroad with a profession, which is in high demand in our country. The remittances to Hungary can change positively the domestic volume and the modernization of education. The negative consequences of remittances can result in the deterioration of domestic productivity. [15]

The migration of healthcare professionals has become a global phenomenon, which deals more and more with health and migration policies. In a country the number of health professionals influences decisively the function of the national health system. It influences indirectly the health status of the population. The consequences of this phenomenon will make their effects felt in the coming decades. The lack of health professionals influences the ability of the health care. The economic performance and quality of life of a country's population depends on the health care system. In case the system is not able to function properly, the right of access to health care gets injured. [17]

The migration of the physicians has four determining factors. First, the recognition of qualifications is automatic within the EU. Second, there are shortages in the healthcare sector. Powerful labour recruitment, which in many cases takes shape aggressively. Third, the human resource management, which in recent times has become a very important factor, because the 
loss of specialists means accentuated burden to the functioning of the supply system. For example, the drastic reduction of the headcounts of family doctors and anaesthesiologists. The last one includes other positive effects, such as sharing of experience, exchange of information, training opportunities. [16]

In 2014, the government announced a significant wage developments plan for the military. The aim of wage development is to retain the existing soldiers and recruit new candidates. The development plan is being implemented in several phases, over a 4-year period. The salary increase would be an average of 50\%. The professionals think that, the life of the military has significantly improved, so fewer soldiers change work. In the HDF a major problem is to attract and retain the voluntary and the contractual soldiers. The results of the research, which investigated the reasons of significant career change, highlight the main reasons of the migration: material and financial reasons, treatment, human relations, disorganization, lack of vision, conditions for spending free time, placement and housing problems. [8]

Some of the military career leavers continue working in an area, where they can utilize their acquired knowledge and skills. In some cases, they switch to another military or security company for a better pay. This shows, that the work is usually for a fixed term, after which it is possible to return to the military. The draining effects of companies is not decisively relevant. [18]

Since military doctors have a special status, the question arises: do they give up their doctor's vocation or their military vocation if they finish their career? Some of the doctors, who finished their military doctor's career, continue practicing as doctors. In this case, we could say, that they give up their military vocation. Is the military a profession for them? Does military mean vocation for them? What is the correct answer, if they think that the military doctor's career is a special exercise of the medical profession? [19]

The doctors, who leave the military and stay in the civil medical sector, have a better bargaining position on the negotiations, because they have special, transferable knowledge. In other words, they have more alternatives, more options to work in the future. For example, they have the possibility to be hired by the private sector, especially by foreign companies where they get a higher salary and during the work they use modern assets. Even the most developed NATO countries face difficulties to fill the short-staffed positions in the military with adequately trained doctors and to guarantee the existing doctors professional and military further development regularly. In Hungary, the number of the professionals researched in this theme is limited, but it has numerous special sociological aspects. However, the problem of the military doctor's discharge shows several problems, which are in the cross-section of the meeting of two professions. [20]

Regarding the contractual soldiers, for example they cannot get pension from the army. Therefore, they join the army for shorter periods. Generally, the entry into force of the statute-2011 CLXVII, conversion of pensions-adversely affected the different groups of the military. [8]

From the answers, it turned out that among the workers at the HDF Military Hospital the most problematic areas are the shortage of staff and exhaustion. The excessive bureaucracy, the lack of moral and material appreciation and the uncertain future perspectives were also highlighted. The other problem is the lack of motivation and professional development. The lack of financial and material conditions, the outdated equipment and long repair times were 
also mentioned. The lack of information flow was also a relevant shortcoming. Interestingly, the lack of sports facilities and the insufficient parking facilities were also added to this list.

The organization's leadership and the good relationship and collaboration with the closest colleagues were mentioned as a positive factor. The cafeteria system, the improving information flow and the development of a quality management system (which means a possibility for development) were also highlighted as a positive aspect.

These results coincide with the online survey organized by the Hungarian Medical Chamber in 2013. According to that survey, the biggest problem is also exhaustion resulting from the average 65 hours working week (hospital work +10 hours part time job +15 hours duty). This leads to burn out, stress, disrupted normal family life which is manifested in a greater number of health problems and chronic and malignant diseases. However, it should be noted that compared to the population, doctors typically smoke less and do more sports activities.

According to the Hungarian Medical Chamber's survey, 75\% of the respondents consider the situation of Hungarian health care system bad and forecast worsening. Many of them (25\%) would not choose the medical profession again.

According to both surveys the physicians are dissatisfied with their earnings, the recognition of their work and their working conditions and their financial situation.

The same positive factor in the two surveys is that they are satisfied with their personal relationships. In the survey conducted by the Hungarian Medical Chamber, the doctors considered their own job performance and housing situations positive.

Both questionnaires asked about the intention of working abroad. At the HDF Military Hospital, this is rising year by year. In 2011 only 18\% of respondents planned that in the meantime in 2015 this ratio went up to $22 \%$. This coincides with the result of the Hungarian Medical Chamber's survey, according to that the ratio is $17 \%$. These forecasts a loss of 5,000 doctors form the total of 30,000 physician members. [1]

Among university pupils, the medical students have the greatest willing of emigration. The Hungarian Association of Residents also sent a questionnaire to the doctors who were already working abroad. Two-thirds of doctors participating in the research had worked previously in the Hungarian health care system, but only $15 \%$ of them had already decided as students to work abroad. Only $2 \%$ of them are planning to come home within 2 years' time. They claimed the biggest deterrent factors are low salaries, the more than 60 hours of work weekly, the impossibility of normal family life and the corruption due to the "gratuity system". The increasing aggression and violence experienced by patients were also mentioned. [2] [3]

In the press, the number of articles on violence against medical personnel has increased: "Staff kicked, spat at, patient received 12 days in custody”, "Disgruntled patient used an axe against medical staff”, "Drunk patient beats nurse at hospital in Békéscsaba”, "He recovered and threw the defibrillator out of the window", and these headlines could be continued endlessly. [4]

Professionals made studies in medical universities in Hungary. The results of the studies did not show differences in various aspects_-family background, financial situation, origin, career circumstances-between the students who are going to be doctors and who are going to leave the doctor's career. The results of the studies showed differences in some of the motivations of the career entrants. Those, who remained in the medical career felt more dedication. For them, it was very important to feel competent in this career. They were better motivated because medicine is a career, where they can help people. [11] 
The $75 \%$ of emigrated doctors would come back if the starting medical salaries increased to an acceptable level (to at least 300,000 HUF which is about 1,000 Euro), and the working conditions and the situation of on-call time improved. I note that the amount mentioned above is the salary of a captain in the Hungarian Army.

Most of the immigrant doctors did not experience integration problems. They considered the quality assurance system based on feedback and questionnaires, discussions, and the fact that many of the proposals usually come to fruition later a positive factor.

They find it important that they can operate and they can work independently, because the gratuity system is not the driver of the structure.

Besides the working hours, there is time to learn and to live well. For administrative tasks, typists are employed. They appreciate that their opinions are asked for and listened to and they are respected as team members. There are training courses arranged and provided for them. However, the doctors mentioned that they need to work hard abroad as well.

In my research among the negative factors, I found the same reasons mentioned above. I need to mention that in some fields some improvements have been made. For example, the parking system and the possibility of sports activities were improved.

At the HDF Military Hospital, the cooperation with close colleagues and the appreciation of the leaders of the hospital were considered good. They found that the quality assurance system also worked well at the Hospital and was leading towards improvements.

\section{Summary}

I compared the results of my research studies with the study carried out by the Hungarian Medical Chamber and the Association of Hungarian Residents. The results show that without money the problem cannot be solved. In addition, the reduction of duty and working hours is important in order to have enough time for normal family life. It is important to obtain some time for living as well. It should be stressed that for the young doctors it is important that they can reach their career goals and they can learn and do operations. It should be mentioned that the provision of sports facilities and adequate parking facilities are also important because of the annual military aptitude test. If there is no change in the willingness of going to work abroad in the future, there will be a serious problem in the civil health care system and it will compromise the combat ability of the Hungarian Army as well.

\section{References}

[1] Szakmai társaságok publikus dokumentumai. Magyar Orvosi Kamar Online: Orvosi látlelet 2013—eredmények. (Medical Record 2013—Results.) 2013. Magyar Orvosi Kamara (online). www.doki.net/dokumentumok.aspx?s_id=176 (Downloaded: 08.10.2013)

[2] Az orvostanhallgatók közt a legerősebb a kivándorlási kedv. (The Willingness of Emigration is Greatest among Medical Students.) medicalonline, 2015. 07. 15. www.medicalonline. hu/eu_gazdasag/cikk/az_orvostanhallgatok_kozt_a_legerosebb_a_kivandorlasi_kedv (Downloaded: 15.07.2015) 
[3] BEB: A kint dolgozók csupán 2 százaléka tervezi, hogy két éven belül hazatelepül. (A Unique Survey of Emigrated Doctors.) weborvos (online), 2012. 09. 05. www.weborvos. hu/egeszsegpolitika/egyedulallo_felmeres_tavozo_orvosokrol/195878/ (Downloaded: 05.09.2012)

[4] MTI: Rúgott, köpött, 12 napot kapott. (Kicked, Spat at, Received 12 Days in Custody.) medicalonline, 2013. 01. 16. www.medicalonline.hu/eu_gazdasag/cikk/rugott_kopott_12_ napot_kapott?utm_source=newsletter\&utm_medium=medicalonline_orvosi_hirlevel\&utm_ campaign=9028 (Downloaded: 16.01 .2013 )

[5] BAKOS CS. A.: A Magyar Honvédség megítélése pályaválasztás előtt álló fiatalok körében. (Image of the Hungarian Defence Forces among the Youth Facing Job Selection.) Hadtudományi Szemle, 61 (2013), 1-5. http://uni-nke.hu/downloads/kutatas/folyoiratok/ hadtudomanyi_szemle/szamok/2013/2013_1/2013_1_hm_bakos_csaba.pdf (Downloaded: 26.05.2016)

[6] LENGYEL ZS.: A katonai pályaszocializáció néhány sajátosságáról (Some Peculiarities about the Military Socialization.) Hadtudományi Szemle, 11 (2008), 69-74. http://uni-nke. hu/downloads/kutatas/folyoiratok/hadtudomanyi_szemle/szamok/2008/2008_1/2008_1_tt_ lengyel_zsuzsanna_69_74.pdf (Downloaded: 22.05.2016)

[7] NÉMET T.: A pályaválasztás és pályaorientáció vizsgálata egy empirikus kutatás során (The Investigation of Career Choice and Career Guidance during an Empirical Research.) Hadtudományi Szemle, 81 (2015), 319-340. http://uni-nke.hu/downloads/kutatas/ folyoiratok/hadtudomanyi_szemle/szamok/2014/2015_1/15_1_alt_nemett.pdf (Downloaded: 27.05.2016)

[8] NAGY-VARGÁNÉ JUHÁSZ,Á.: A motiváció szerepe a Magyar Honvédségben. (The Role of Motivation in the HDF.) Bolyai Szemle, 122 (2010), 1-12.

[9] NAGYNÉ BERECZKI SZ:: Speciális katonai beosztások orvosi és pszichológiai alkalmasság-vizsgálatának története Magyarországon. (The History of Medical and Psychological Aptitude Tests for Special Army Assignments in Hungary.) Bolyai Szemle, 162 (2007), 7-25. http://portal.zmne.hu/download/bjkmk/bsz/bszemle2007/2/01_ nagynebereczki.pdf (Downloaded: 27.05.2016)

[10] BODNÁR K., SZABÓ L. T.: A kivándorlás hatása a hazai munkaerőpiacra. (The Impact of Emigration on the Domestic Labour Market.) In. MNB-tanulmányok, 114. Budapest: MNB, 2014. www.mnb.hu/letoltes/a-kivandorlas-hatasa-a-hazai-munkaeropiacra.pdf (Downloaded: 29. 05. 2016)

[11] MOLNÁR R., NYÁRI T., MOLNÁR P.: Az orvostanhallgatók pályánmaradásra, pályaelhagyásra vonatkozó elképzelései. (Medical Students' Ideas about Staying and Career Change). Orvosi Hetilap, 14918 (2008), 843-848. DOI: https://doi.org/10.1556/oh.2008.28326

[12] BUDNIK K. Z.: Do those Who Stay Work Less? On the Impact of Emigration on the Measured TFP in Poland. In. Working Paper, 113. Warsaw: National Bank of Poland, 2012. www.nbp.pl/publikacje/materialy_i_studia/113_en.pdf (Downloaded: 28.05.2016)

[13] EPPICH GY., KÖLLŐ J.: Foglalkoztatás a válság előtt, közben és után. (Employment before, during and after the Crisis.) Társadalmi Ripot, 167 (2014), 157-178. http://tarki.hu/ adatbank-h/kutjel/pdf/b329.pdf (Downloaded: 23.05.2016)

[14] BLASKÓ ZS., LIGETI A. S., SIK E.: Magyarok külföldön-Mennyien? Kik? Hol? (Hungarians abroad - How many? Who? Where?) In. Társadalmi riport, 2014. Budapest: Tárki. 353-359. www.tarki.hu/adatbank-h/kutjel/pdf/b337.pdf (Downloaded: 26.11.2015) 
SZ. JASZTRAB: Effects of Employee Satisfaction on Attrition of Military Officers...

[15] CHAMI, R., FULLENKAP, C., JAHJAH, S.: Are Immigrant Remittance Flows a Source of Capital for Development? In. IMF Working Paper, WO/03/189. Washington D.C.: IMF, 2003. www.imf.org/external/pubs/ft/wp/2003/wp03189.pdf (Downloaded: 24.05.2016)

[16] GAIZAUSKIEN, A., GRABAUSKAS, V., KUCINSKIENE, Z.: Physician Planning in Lithuania in 1990-2015. Policy Documentation Center, 2000. http://pdc.ceu.hu/ archive/00002469/01/LGP_leidinys_engl.pdf (Downloaded: 29.05.2016)

[17] EKE E., GIRASEK E., SZÓCSKA M.: A migráció a magyar orvosok körében (Migration of the Hungarian Doctors.) Statisztikai Szemle, 93 7-8 (2007), 795-827.

[18] KATONA B.: A katonai és biztonsági magánvállalatok tevékenysége és a fegyveres testületeknél szolgálatot teljesítők pályaelhagyása közti összefüggések (Correlation between the Private Military and Security Companies' Activities and the Armed Forces Achievers Leaving.) (2011), 4-5. http://193.224.76.4/download/konyvtar/digitgy/publikacio/katona_ bela01.pdf. (Downloaded: 26.05.2016)

[19] SZEKENDI GY.: A Magyar Honvédség békeidőszaki személyi állományának foglalkoztatási viszonyai, különös tekintettel a honvédek jogállására. (The Staff Conditions of Employment in Peace Time in the HDF.) Budapest: Magyar Közlöny Lapés Könyvkiadó, s.d. http://magyaryprogram.kormany.hu/download/2/1b/a0000/20_JOG_ Hjt_AROP2217.pdf (Downloaded: 27.05.2016)

[20] POPOV, M. N.: A Confluence of Factors: Canadian Forces Retention and the Future Force. (Thesis for Master of Defence Studies) Toronto: Canadian Forces College, 2011. www.cfc.forces.gc.ca/259/290/297/286/Popov.pdf (Downloaded: 26.05.2016) 